Acta Horticulturae et Regiotecturae 2

Nitra, Slovaca Universitas Agriculturae Nitriae, 2019, pp. 61-64

\title{
MEASUREMENT OF VOLUMETRIC WATER CONTENT BY GRAVIMETRIC AND TIME DOMAIN REFLECTOMETRY METHODS AT FIELD EXPERIMENT WITH BIOCHAR AND N FERTILIZER
}

\author{
Lucia TOKOVÁ*, Dušan IGAZ, Elena AYDIN \\ Slovak University of Agriculture in Nitra, Slovak Republic
}

\begin{abstract}
There are many methods used for soil water content measurement which we can divide into direct gravimetric methods from using soil samples or indirect methods that are based on the measurement of another soil property which is dependent on soil moisture. The paper presents the findings of volumetric water content measurements with gravimetric and time domain reflectometry (TDR) methods. We focused on four variants in the field experiment in Dolná Malanta (Slovakia): control variant (B0+N0), variant with biochar at dose 20 t.ha $^{-1}$ without $\mathrm{N}$ fertilizer (B20+N0), variant with biochar 20 t.ha $^{-1}$ and $\mathrm{N}$ fertilizer $160 \mathrm{~kg}^{-h a^{-1}}$ (B20+N160) and variant with biochar 20 t.ha ${ }^{-1}$ and $\mathrm{N}$ fertilizer $240 \mathrm{~kg} \cdot \mathrm{ha}^{-1}$ (B20+N240). TDR is nowadays a well-established dielectric technique to measure volumetric water content; however, its accuracy is influenced by high concentration of salts in soil. In this paper, we evaluated the effect of added $\mathrm{N}$ fertilizer on the measuring accuracy of HydroSense II device that is operating under the TDR principle.
\end{abstract}

Keywords: gravimetric method, TDR calibration, N fertilizer, soil salinization

Measurement of soil water content is fundamental to many investigations in agriculture, horticulture, ecology, forestry, hydrology, civil engineering, waste management and other environmental fields. Water present within soil pores is called soil water content which is accepted as reference to the water that may be evaporated from soil by heating from 100 up to $110^{\circ} \mathrm{C}$, but usually to $105^{\circ} \mathrm{C}$, until there is no further weight loss. This is the basis of the gravimetric method which is the oldest established and the only truly direct method of water content determination which requires samples for oven drying. It is the standard reference against which other techniques are normally calibrated. The other techniques rely on measurement of another soil property which is dependent on soil moisture (Smith and Mullins, 2001).

According to Smith and Mullins (2001), the development of dielectric methods since 1980 has introduced opportunities for rapid collection of soil water content data at short time intervals and permitted automation and logging of measurements. The ability to log soil water content automatically has opened ways of soil water monitoring and soil hydrological research that had previously been impossible. The most common dielectric method used is time domain reflectometry (TDR). TDR is nowadays a wellestablished technique to measure volumetric water content using the frequency in the range from $10 \mathrm{MH}_{\mathrm{z}}$ to $12 \mathrm{GH}_{\mathrm{z}}$.

For saline soils, in certain cases the imaginary part of the dielectric constant can also affect the TDR reading. When the electrical conductivity (EC) of pore water is higher than 8-10 dS.m $\mathrm{m}^{-1}$, the TDR overestimates volumetric water content. There are conflicting results regarding the effect of the EC on volumetric water content. TDR values in some cases could be bias free, sometimes underestimated, sometimes overestimated, and sometimes both of them under- and overestimated relative to gravimetric method determination. The influence of high EC on TDR measurements seems to be soil specific (Nadler, Gamliel and Peretz, 1999; Bouksila et al., 2008). Also Wyseure, Mojid and Malik (1997) stated that electrical conductivity of a saline soil influences the measurement of the soil water content by TDR. Further, they stated that if the bulk electrical conductivity is kept less than $2 \mathrm{dS} \cdot \mathrm{m}^{-1}$, the overestimation stays within reasonable limits and can be disregarded. The study of Hook, Ferré and Livingston (2004) is focused on determination of the performance limits of TDR probes for measuring water content in high EC sands. Time domain measurement shows that there is an increase in the travel time of a pulse with increasing pore water salinity and that the variability of travel time measurements also increases with the pore water EC. According to Bonnell, Broughton and Enright (1991), the TDR technique can be used to ascertain absolute solution salinity levels, but only relative levels of bulk soil electrical conductivity are possible to be determined.

The main aim of the presented paper was to perform measurements of volumetric soil water content for four experimental variants $(\mathrm{B} 0+\mathrm{N} 0, \mathrm{~B} 20+\mathrm{N} 0, \mathrm{~B} 20+\mathrm{N} 160$ and $\mathrm{B} 20+\mathrm{N} 240)$ in the field experiment at Dolná Malanta

Contact address: Ing. Lucia Toková, Slovak University of Agriculture in Nitra, Faculty of Horticulture and Landscape Engineering, Department of Biometeorology and Hydrology, Hospodárska 7, 94901 Nitra, Slovakia, tel.: +421 376415252 , e-mail: tokovalucia@gmail.com 
(Slovakia). Soil water content was determined from the collected undisturbed soil samples by gravimetric method as well as by the TDR method. Another goal was to perform a calibration on a particular device we used for water content measurements in the field.

\section{Material and methods}

\section{Field site}

Several variants of the field experiment at the locality Dolná Malanta in Nitra region of Slovakia with different doses of biochar and $\mathrm{N}$ fertilisers to examine the effect of biochar application on greenhouse gas emissions (Horák et al., 2017), soil water regime (Igaz, Horák and Domanová, 2015) other soil properties (Igaz et al., 2018; Juriga et al., 2018) and crop yields (Kondrlová et al., 2017; Kondrlová, Horák and Igaz, 2018) were established in the experimental area in March 2014. Biochar for this field experiment was produced from the mixture of paper fibre and cereal husks by pyrolysis at $550{ }^{\circ} \mathrm{C}$ for $30 \mathrm{~min}$ and applied into the top layer of soil $(0-10 \mathrm{~cm})$. According to Igaz et al. (2018) the altitude of the site is $175 \mathrm{~m}$, the soil is classified as Haplic Luvisol and the topsoil contains $249 \mathrm{~g} \cdot \mathrm{kg}^{-1}$ of clay, $599 \mathrm{~g} \cdot \mathrm{kg}^{-1}$ of silt and $152 \mathrm{g.kg}^{-1}$ of sand, giving it a silt loam texture. The area of interest was used for agricultural production and research purposes and the whole site was sown by maize (Zea mays L.) during the sampling in 2017.

\section{Soil sampling and subsequent analyses}

We executed soil sampling on four variants in the experiment: control variant without biochar and $\mathrm{N}$ fertilizer (B0+N0), variant with biochar at dose 20 t.ha $^{-1}$ without $\mathrm{N}$ fertilizer (B20+N0), variant with biochar at dose 20 t.ha $^{-1}$ and $\mathrm{N}$ fertilizer at dose $160 \mathrm{~kg} \cdot \mathrm{ha}^{-1}(\mathrm{~B} 20+\mathrm{N} 160)$ and variant with biochar at dose 20 t.ha ${ }^{-1}$ and $\mathrm{N}$ fertilizer at dose $240 \mathrm{~kg} \cdot \mathrm{ha}^{-1}$ (B20+N240). Undisturbed soil samples $\left(100 \mathrm{~cm}^{3}\right)$ were taken from desired depths at 3 randomly selected locations at plots representing each of 4 variants for determination of selected soil characteristic - in our case it was volumetric water content (VWC). The soil samples were kept in airtight sealed containers to prevent losses of moisture prior measurement in laboratory. The soil samples were weighed and dried in an oven at $105^{\circ} \mathrm{C}$. After removing from oven and slow cooling to room temperature, the dry soil samples were weighed again. Soil sampling was conducted once per week during two month period (April and May 2017) and once a month during the rest of the vegetation period of maize (June to October 2017).

VWC (\%) in the soil was calculated by a specific formula (Antal and lgaz, 2012):

$$
V W C=\frac{V_{w}}{V_{t}}=\frac{\left(m_{1}-m_{2}\right) \cdot \rho_{w}}{V_{t}} \cdot 100
$$

where:

$$
\begin{aligned}
& V_{w}-\text { the volume of soil water }\left(\mathrm{cm}^{3}\right) \\
& V_{t}-\text { the volume of soil sample }\left(\mathrm{cm}^{3}\right) \\
& m_{1} \quad-\text { the weight of wet soil }(\mathrm{g}) \\
& \mathrm{m}_{2} \quad-\text { the weight of dry soil }(\mathrm{g}) \\
& \rho_{w} \quad-\text { the soil water density }\left(\mathrm{g} \cdot \mathrm{cm}^{-3}\right)
\end{aligned}
$$

\section{Equipment and instrumentation}

At the same time, volumetric soil water content measurements were performed by HydroSense II probe (model CS659) (Campbell Scientific, Inc. ${ }^{\circledR}$ ) using the TDR principle of measurement. This is an indirect method of VWC measurement based on the travel time of a high frequency electromagnetic pulse $\left(\mathrm{MH}_{\mathrm{z}} \mathrm{GH}_{\mathrm{z}}\right)$ through the soil. This travel time is used to calculate the dielectric constant of the material. The TDR probes are inserted directly into the soil for in situ measurement at the desired soil depths. The probe is an easyto-use portable device for measuring VWC in agricultural soils. The calibration coefficients fixed in the HS2 sensor were determined in laboratory studies on typical soils. Its accuracy is $\pm 3 \%$ VWC in typical soils with solution EC $\leq 6.5 \mathrm{dS} . \mathrm{m}^{-1}$. When measuring atypical soils, user determined coefficients can often be applied. A soil specific calibration can be performed using an independent measure of water content such as gravimetric analysis (HS2, 2019).

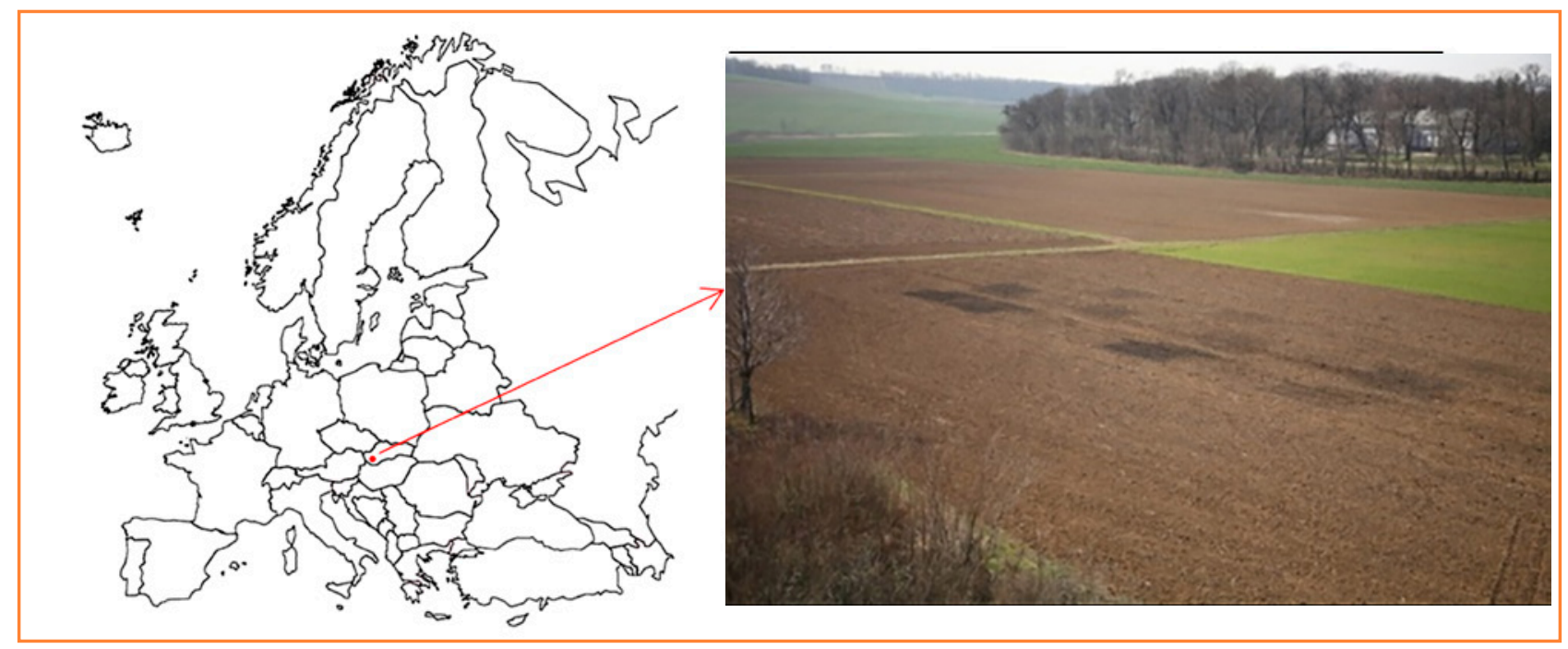

Figure 1 Field site location and photo of the experimental area Photo: Tárník, 2014 


\section{Results and discussion}

\section{TDR calibration}

Indirect methods usually require calibration for more accurate measurements in the particular investigated soil. The probe was calibrated using linear dependence relationship between standard gravimetric and TDR method. That means that there was a linear equation for a given dependence, and when calibrating the instrument, the values measured by the instrument were substituted as a parameter $x$ in the equation $y=a x+b$. The graphical trend of the calibration equations for variants $\mathrm{B} 0+\mathrm{N} 0, \mathrm{~B} 20+\mathrm{N} 0, \mathrm{~B} 20+\mathrm{N} 160$ and B20+N240 is shown in Fig. 2.

\section{Effect of $\mathrm{N}$ fertilizer on TDR measurement}

The graphical course of soil water content measured by both methods (for the TDR method both before and after instrument calibration) during the whole growing season of the crop in 2017 can be observed in Fig. 3 (variant $\mathrm{B} 0+\mathrm{N} 0)$, in Fig. 4 (B20+N0), in Fig. 5 for (B20+N160) and in Fig. 6 for (B20+N240). As it can be seen in Fig. 3 to Fig. 6, at the beginning of the growing season (April - June), the soil water content was higher (25-30\% vol.). During this period, the soil moisture measured by both methods had the same course in all four experimental variants. The figures further show that during the dry summer period (June Sept), the higher nitrogen load affected the accuracy of the instrument when compared to the standard gravimetric method. The instrument readings were much lower at the $\mathrm{B} 20+\mathrm{N} 160$ and B20+N240 variants. In the following period (Sept - Oct), the soil moisture increased due to the higher rainfall, and it again had approximately the same course for both methods.

Prior to the probe calibration, the measured volumetric water content differed in the range of 0 up to $5 \%$ when compared to the gravimetric method. This difference was modified after the specific calibration to range $0-2 \%$. For non-fertilized treatments the observed differences in water content might have been caused by the TDR device measurement accuracy. However, the differences between the TDR and the gravimetric measurements were higher for fertilized treatments.

Depending on the soil characteristics at the specific site, the electrical conductivity values may be affected by the salt content in the soil, soil texture and soil moisture. One of the disadvantages of TDR devices is their inaccurate measurement in soils with higher salinity. We assume that $\mathrm{N}$ fertilization could increase the salt concentration in the soil and thus

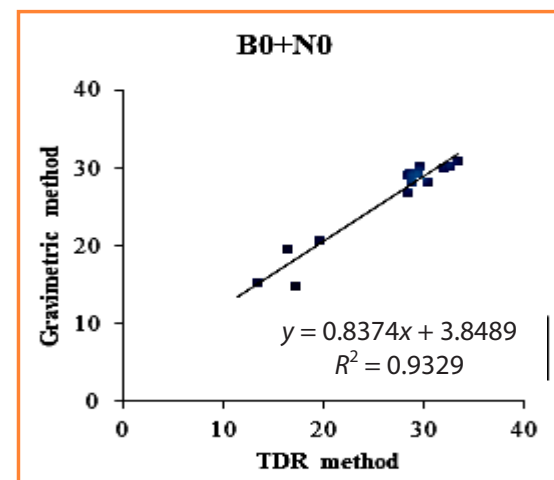

$\mathrm{B20}+\mathrm{N160}$

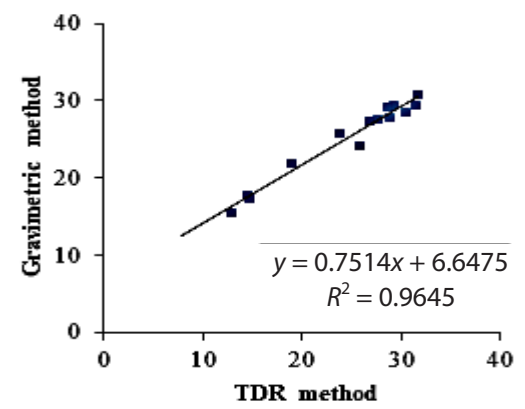

B20 + NO

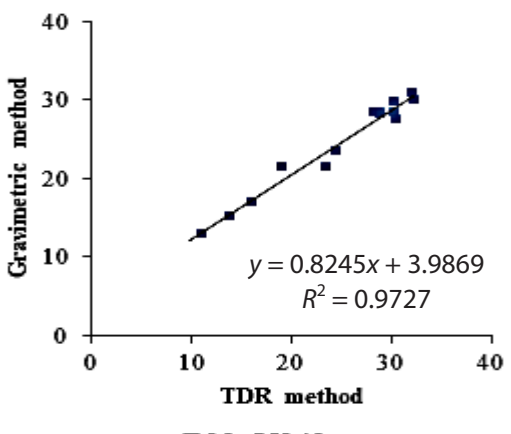

B20 $+\mathbf{N 2 4 0}$

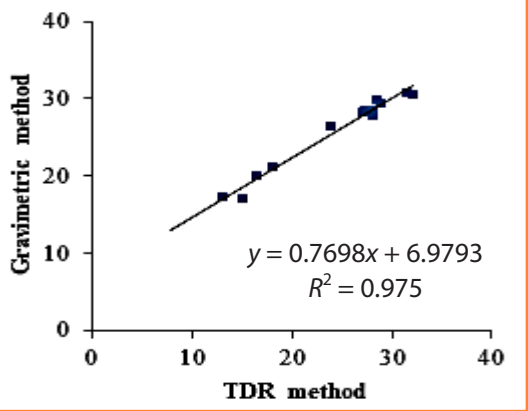

Figure 2 Graphical trend of calibration equations for treatments $\mathrm{B} 0+\mathrm{N} 0, \mathrm{~B} 20+\mathrm{NO}$, B20+N160 a B20+N240

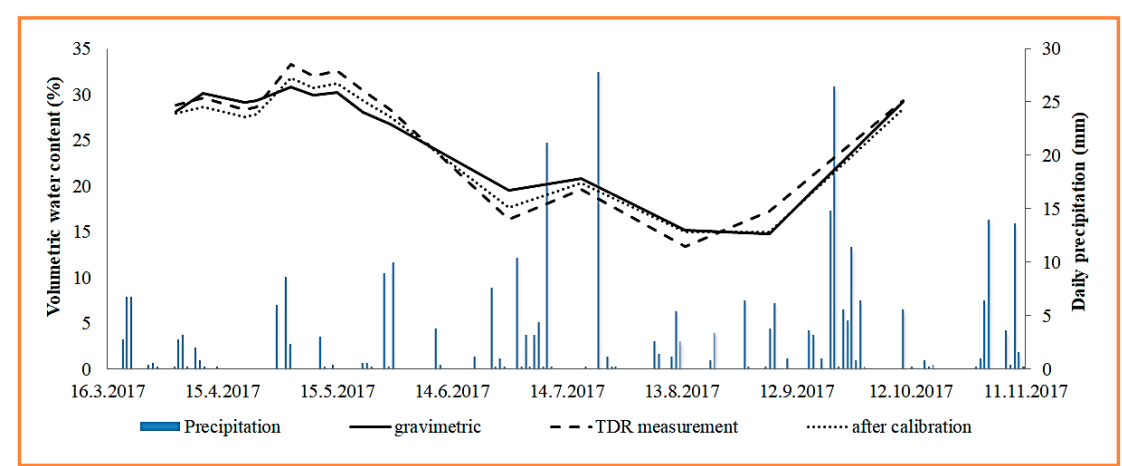

Figure 3 Graphical course of VWC for $\mathrm{B} 0+\mathrm{N} 0$

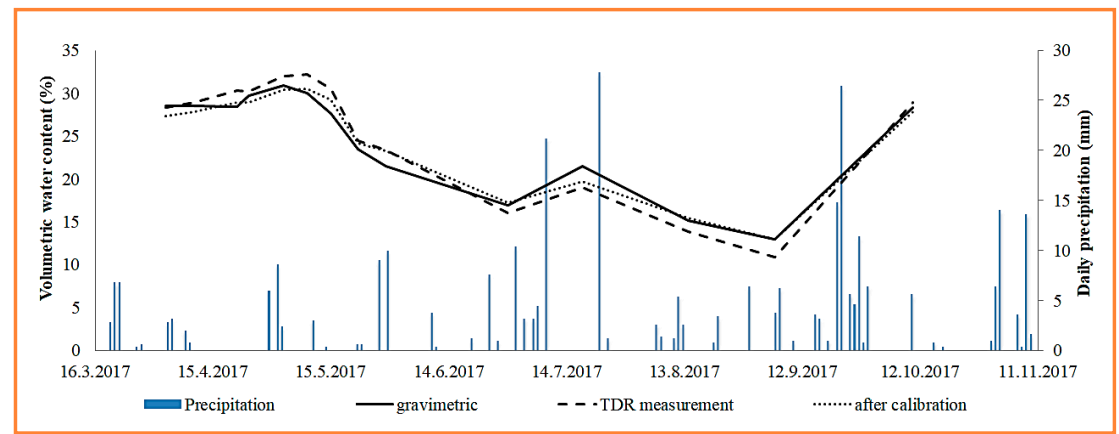

Figure 4 Graphical course of VWC for B20+NO 


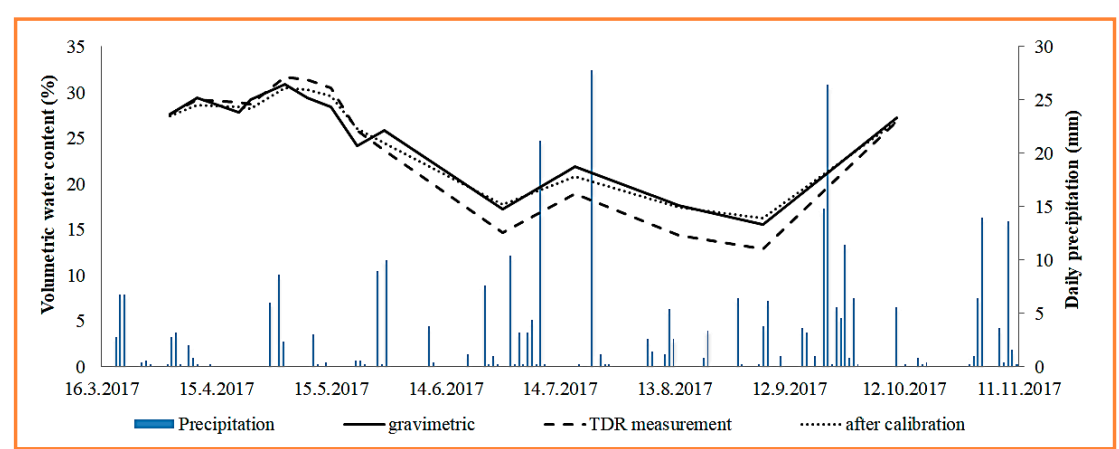

Figure 5 Graphical course of VWC for B20+N160

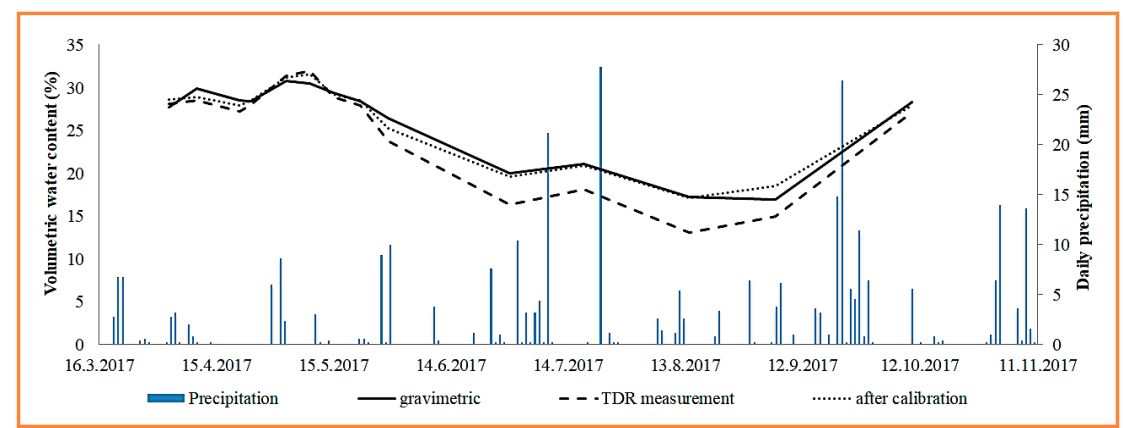

Figure 6 Graphical course of VWC for B20+N240

its electrical conductivity. Several authors, including Jingpei et al. (2015) have investigated the impact of $\mathrm{N}$ fertilizers on increasing soil salinity. In their particular study, nitrogen was applied at high doses of 600 and 1,200 kg.ha-1. The authors state that salinity had increased significantly after $\mathrm{N}$ input. The increase in soil salinity was attributed to the nitrification of excess N fertilizer. Similarly, Bryla, Shireman and Machado (2010) pointed out that the application of granular $\mathrm{N}$ fertilizer may increase the electrical conductivity of the soil solution.

\section{Conclusions}

In this paper we focused on the measurement of soil volumetric water content by the gravimetric method and the TDR method in the field experiment in Dolná Malanta. Soil water content was measured in four experimental variants $\mathrm{B} 0+\mathrm{N} 0, \mathrm{~B} 20+\mathrm{N} 0, \mathrm{~B} 20+\mathrm{N} 160$ and $\mathrm{B} 20+\mathrm{N} 240$. We have found that in the variants with added nitrogen fertilizer (B20+N160 and B20+N240) the accuracy of measurement by the HydroSense II operating on the TDR method was lower when compared to the gravimetric method. According to Jingpei et al. (2015) and Bryla, Shireman and Machado (2010) N fertilization can increase soil salinity. We therefore assume that also in our case the measurement inaccuracy may be caused by increased salt concentration in the soil. To increase the measurement accuracy by the used device, we performed a specific calibration on a particular soil and thus adjusted the soil water content.

\section{Acknowledgments}

This study was financially supported by the projects KEGA 019SPU-4/2017, 026SPU-4/2017 and VEGA 1/0064/19.

\section{References}

ANTAL, J. - IGAZ, D. 2012. Aplikovaná agrohydrológia. Nitra : SPU, 2012. ISBN 978-80-552-0731-5.

BONNELL, R. B. - BROUGHTON, R. S. - ENRIGHT, P. 1991. The measurement of soil moisture and bulk soil salinity using time domain reflectometry. In Canadian Agricultural Engineering, vol. 33, 1991, no. 2, pp. 225-229. BOUKSILA, F. - PERSSON, M. - BERNDTSSON, R. - BAHRI, A. 2008. Soil water content and salinity determination using different dielectric methods in saline gypsiferous soil (Détermination de la teneur en eau et de la salinité de sols salins gypseux à l'aide de différentes méthodes diélectriques). In Hydrological Journal, vol. 53, 2008, no. 1, pp. 253-265. Online: https://doi.org/10.1623/ hysj.53.1.253

BRYLA, D. R. - SHIREMAN, A. D. - MACHADO, R. M. A. 2010 Effects of Method and Level of nitrogen Fertilizer Application on Soil $\mathrm{pH}$, Electrical Conductivity, and Availability of Ammonium and Nitrate in Blueberry. In
Acta horticulturae, 2010, (868). Online: DOI: 10.17660/ActaHortic.2010.868.8

HOOK, W. R. - FERRÉ, T. P. A. - LIVINGSTON, N.J. 2004. The Effects of Salinity on the Accuracy and Uncerainty of Water Content Measurement. In Soil Science Society of America Journal, vol. 68, 2004, pp. 47-56.

HORÁK, J. - KONDRLOVÁ, E. - IGAZ, D. ŠIMANSKÝ, V. - FELBER, R. - LUKÁČ, M. BALASHOV, E.V. - BUCHKINA, N.P. - RIŽIJA, E. - JANKOWSKI, M. 2017. Biochar and biochar with $\mathrm{N}$-fertilizer affect soil $\mathrm{N}_{2} \mathrm{O}$ emission in Haplic Luvisol. In Biologia, vol. 72, 2017, no. 9, pp. 995-1001. ISSN 0006-3088.

HS2. 2019. Product Manual: HS2 and HS2P (HydroSense II). (c) 2011-2019. Online: https://s.campbellsci.com/documents/us/ manuals/hs2.pdf

IGAZ, D. - HORÁK, J. - DOMANOVÁ, J. 2015. The impact of biochar on the soil water characteristics In SGEM 2015.

IGAZ, D. - ŠIMANSKÝ, V. - HORÁK, J. KONDRLOVÁ, E. - DOMANOVÁ, J. - RODNÝ, M. - BUCHKINA, N.P. 2018. Can a single dose of biochar affect selected soil physical and chemical characteristics? In Journal of hydrology and hydromechanics, vol. 66, 2018, no. 4, pp.421-428. ISSN 0042-790X.

JINGPEI, H. - JIACHUN, S. - LINGZAO, Z. JIANMING, X. - LAOSHENG, W. 2015 Effects of nitrogen fertilization on the acidity and salinity of greenhouse soils. In Environmental Science and Pollution Research, vol. 22, 2015, no. 4, pp. 2976-2986. ISSN 0944-1344. Online: https://doi.org/10.1007/s11356-014-3542-z

JURIGA, M. - ŠIMANKSÝ, V. - HORÁK, J. KONDRLOVÁ, E. - POLLÁKOVÁ, N. - BUCHKINA, N.P. - BALASHOV, E. 2018. The effect of different rates of biochar and biochar in combination with $\mathrm{N}$ fertilizer on the parameters of soil organic matter and soil structure. In Journal of Ecological Engineering, vol. 19, 2018, no. 6, pp. 153-161. ISSN 2081-139X.

KONDRLOVÁ, E. - HORÁK, J. - IGAZ, D. DOBIÁŠOVÁ, D. 2017. The possibility of using digital images in assessment of plant canopy development and weed spread. In Acta Horticulturae et Regiotecturae, vol. 20, 2017, no. 2, pp. 35-39.

KONDRLOVÁ, E. - HORÁK, J. - IGAZ, D. 2018. Effect of biochar and nutrient amendment on vegetative growth of spring barley (Hordeum vulgare L. var. Malz). In Australian journal of crop science, vol. 12, 2018, no. 2, pp. 178-184. ISSN 1835-2693.

NADLER, A. - GAMLIEL, A. - PERETZ, I. 1999. Practical aspects of salinity effect on TDRmeasured water content: a field study. In Soil Science Society of America Journal, vol. 63, 1999, no. 5, pp. 1070-1076.

SMITH, A.K. - MULLINS, E. CH. 2001. Soil and Environmental Analysis Physical Methods. New York : Marcel Dekker, Inc, 2001. ISBN 0-8247-0414-2.

WYSEURE, G. C. L. - MOJID, M. A. - MALIK, M. A. 1997. Measurement of volumetric water content by TDR in saline soils. In European Journal of Soil Science, vol. 48, 1997, pp. 347-354. 